University of Belgrade

Faculty of Mechanical Engineering

Boško Rašuo

Full Professor

University of Belgrade

Faculty of Mechanical Engineering

Marta R. Trninić

Research Associate University of Belgrade

Faculty of Mechanical Engineering

Vuk M. Adžić

Research Associate University of Belgrade Faculty of Mechanical Engineering

\title{
Mirko Dinulović \\ Full Professor \\ Numerical Modeling of Nomex Honeycomb Core Composite Plates at Meso Scale Level
}

Honeycomb core composite plates are becoming more important in the construction of primary aerospace structures. Nowadays, these types of materials are used for construction of fuselage skins, central and outer wing boxes, engine tail cones, landing gear doors, command surfaces like spoilers and ailerons etc. To determine the stress strain field in loaded honeycomb plates elastic coefficients are required. In the present work, a method for determining all required elastic coefficients for the core and plates is presented. Using experimentaly obtained values for Nomex paper (type 410) and phenolic resin matrerial model is presented and FEA model of composite plate with honeycom core is createted and three point bend test is simulated. Numericaly obtained stress and strain values are compared to the experiment. Good agreement between proposed material model and experimentaly obtained values is observed.

Keywords: Honeycomb core, Nomex, Composite plate, material model..

\section{INTRODUCTION}

Composite sandwich panels are widely used in different types of structures where high stiffness and low structural mass is required. Industries that use composite sandwich panels are primarily aerospace, automotive and construction industry. Typical sandwich panel consists of two main building blocks, rigid upper and lower plate, usually referred as face sheets that carry inplane loads and bending moments and the core which carries mainly the transverse loads [1].

Howbeit, nowadays at material level many different configurations are used. In this paper the focus is given to panels that consist of polymer matrix composite face sheets and hollow hexagonal nomex core. This type of structure is often used in aircraft industry, for primary and secondary aircraft structures, like fuselage skins, central and outer wing boxes, engine tail cones, landing gear doors, command surfaces such as spoilers and ailerons and leading edges [2,3].

In comparison with monolithic composite plates and shells, composite sandwich panels behave more efficiently when bearing transverse and bending loads. This type of structure is presented in Figure 1.

However, questions of stress-strain field calculation and hence, modeling techniques do raise with the increasing use of composite sandwich panels in today's light weight structural components.

One of the approaches, when analysing the sandwich panels is to replace the real honeycomb structure with an equivalent continuum model in terms of their e ective properties rather than by consideration of their real cellular structure. This approach is effective since the computational time for finite element honeycomb sandwich models increase rapidly as the number of cells

Received: May 2020, Accepted: July 2020

Correspondence to: Dr Mirko Dinulović

Faculty of Mechanical Engineering,

Kraljice Marije 16, 11120 Belgrade 35, Serbia

E-mail: mdinulovic@mas.bg.ac.rs

doi:10.5937/fme2004874D

(C) Faculty of Mechanical Engineering, Belgrade. All rights reserved in the core increase. Calculation of equivalent in-plane Effective Elastic Moduli $\mathrm{E}_{1}$ and $\mathrm{E}_{2}$ and Effective shear modulus $\mathrm{G}_{12}$ of the honeycomb core was investigated by many researchers over past two decades and a review of mathematical models for in-plane moduli of Honeycomb Structures is given in $[4,5]$.

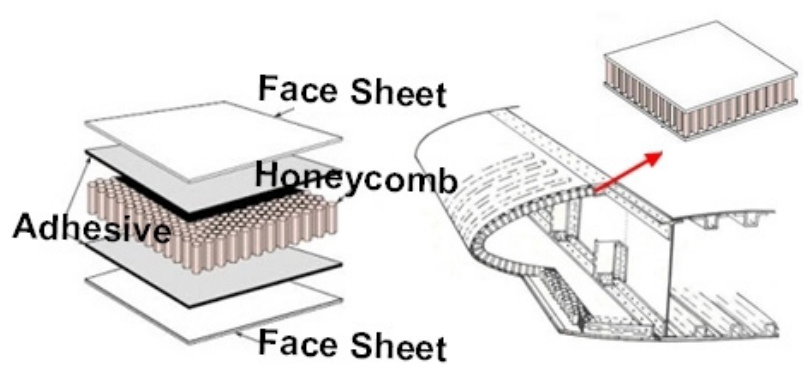

Figure 1. Composite plate with honeycomb core, and typical application on aero structure

In many analyses, like dynamic analysis of composite plates or impact analysis to name a few, the equivalent approach does not render satisfactory results, since the stresses in the equivalent, solid core, are averaged and high stress areas (like plate edges and plate-core contact areas) cannot be computed correctly. Thus, it is not possible to account for local failure modes of the hexagonal cell structure. Furthermore, in mathematical models for in-plane moduli of honeycomb structures it is assumed that the core material is purely isotropic, whereas the experimental results on nomex paper show clear orthotropic behaviour. Therefore, for the analyses mentioned earlier, the detailed (micromechanical) model of the core is required to obtain satisfactory results for the stress-strain and displacement fields [6].

Needleman [7] defined 'mesoscale continuum mechanics' as 'intermediate between direct atomistic and an unstructured continuum description of deformation processes'. Material behaviour at this scale (between $1 \mu \mathrm{m}$ and $1 \mathrm{~mm}$ ) falls into the area of materials science, and is analysed using methods of both physics 
and mechanics of materials, including micromechanics and fracture mechanics.

More detailed classification, with meso I and meso II levels was proposed by Panin [8]. The meso I level links to inside microstructural elements (grains), whereas the meso II level is associated with the conglomerates of microstructural elements.

Mishnaevsky $\mathrm{Jr}$ and Schmauder [9] defined the mesolevel in the material structure as a range of scale levels which are in between the two to three orders of magnitude superior than flaws in the structure (which is in the $10^{-9}-10^{-5} \mathrm{~m}$ range)

In recent years the development of computational technology has rendered the possibility of modeling the orthotropic cores, as well as composite plates at micro and meso scale material levels, and possibility to perform even dynamic and non-linear analysis of complete honeycomb core structure at reasonable computational cost.

\section{NOMEX HONEYCOMB CORE COMPOSITE PLATE MATERIAL MODEL}

\subsection{Nomex Core production process}

There are two main production methods in Honeycomb cores manufacturing, These are expansion method and Corrugated Process of Honeycomb Manufacture. Honeycomb is made mainly by the expansion method. For high density honeycomb materials the corrugated process is mostly used.

Nomex honeycomb core is manufactured using special form of paper (nomex paper) which is a form of paper with embedded aromatic polyamide (aramid fibers). The Nomex paper itself, provides high mechanical integrity coupled with moisture insensitivity, chemical, radiation and flame resistance. These unique characteristics make it the perfect candidate for lightweight applications.(Figure 2)

An expanded Nomex paper (initially unstable) is dipped into phenolic resin, and further subjected to curing process rendering a strong solid structure (honeycomb core).

Expansion method is generally used to produce the honeycomb core. At the first stage of production process, small adhesive stripes are applied to on the Nomex paper which is, at this stage in the flat sheet form. Adhesive strips follow strict staggered pattern.

In the next step of honeycomb core production process, sheets of paper are stacked and cured. After competition of curing process, the honeycomb block before expansion is formed ("HOBE" block).

After HOBE block formation, the block is pulled on a sides forming expanded structure in the form of hexagon cell structure shape. This expanded paper honeycomb cell structure is dipped into phenolic resin. In order to achieve phenolic step-growth polymerization the expanded cell structure is subjected to further curing process. Once cured, the blocks are cut to the honeycomb sheets to the desired thickness

Complete Nomex honeycomb core production process by expansion is depicted in the following picture (Figure 3)
The corrugated process of honeycomb manufacture is normally used to produce products in the higher density range. In this process adhesive is applied to the corrugated nodes, the corrugated sheets are stacked into blocks, the node adhesive cured, and sheets are cut from these blocks to the required core thickness.

\subsection{Nomex paper elastic coefficients}

Nomex paper is available in rolls and sheets of various withs and thicknesses ranging from 0.05 to $0.76 \mathrm{~mm}$. It is produced from short fibers and binder elements. Both fibers and binders are of aramid polymer. The paper, as a main building block of the core is formed into sheet structure on a paper machine, which is later calendered to obtain desired hexagonal form. Nomex paper is laminated with polymer, usually phenolic resin.

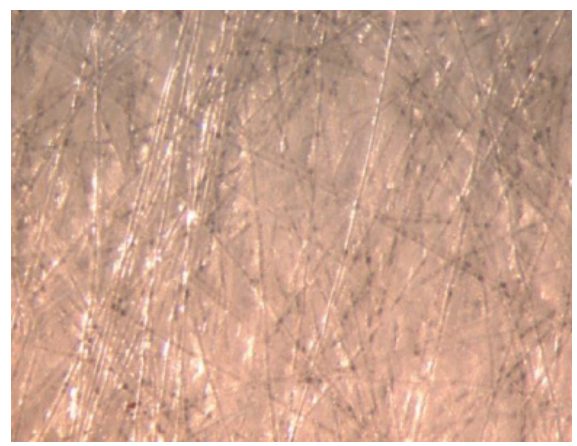

Figure 2. Nomex paper T410 microstructure

With the higher moisture content, certain properties of Nomex type 410 can be improved. This is applicable to the tear strength and toughness primarily. If the Nomex Type 410 paper is exposed to $95 \%$ relative humidity the dimensions will increase at most $1 \%$ in the machine direction and $2 \%$ in the cross direction (which also proves the orthotropic nature of the Nomex paper). If the paper is dried this process may be reversed. The rate of dimensions change is directly related to the paper thickness The environmental humidity produces dimensional changes less than $1 \%$.

The structure of Nomex paper at material level can be regarded as orthotropic and in the form of thin sheets, as described previously, thin-walled (Figure 4). For thin orthotropic structure, four independent elastic coefficients are required to describe the stress- strain state:

$$
\begin{aligned}
& {\left[\begin{array}{c}
\sigma_{0} \\
\sigma_{90} \\
\tau_{12}
\end{array}\right]=\left[\begin{array}{ccc}
Q_{11} & Q_{12} & 0 \\
Q_{21} & Q_{22} & 0 \\
0 & 0 & Q_{66}
\end{array}\right]\left[\begin{array}{c}
\varepsilon_{0} \\
\varepsilon_{90} \\
\gamma_{12}
\end{array}\right]=} \\
& =\left[\begin{array}{ccc}
\frac{E_{0}^{p}}{1-v_{12}^{p} v_{21}^{p}} & \frac{v_{12}^{p} E_{90}^{p}}{1-v_{12}^{p} v_{21}^{p}} & 0 \\
\frac{v_{21} E_{0}^{p}}{1-v_{12}^{p} v_{21}^{p}} & \frac{E_{90}^{p}}{1-v_{12}^{p} v_{21}^{p}} & 0 \\
0 & 0 & G_{12}^{p}
\end{array}\right]\left[\begin{array}{c}
\varepsilon_{0} \\
\varepsilon_{90} \\
\gamma_{12}
\end{array}\right]
\end{aligned}
$$




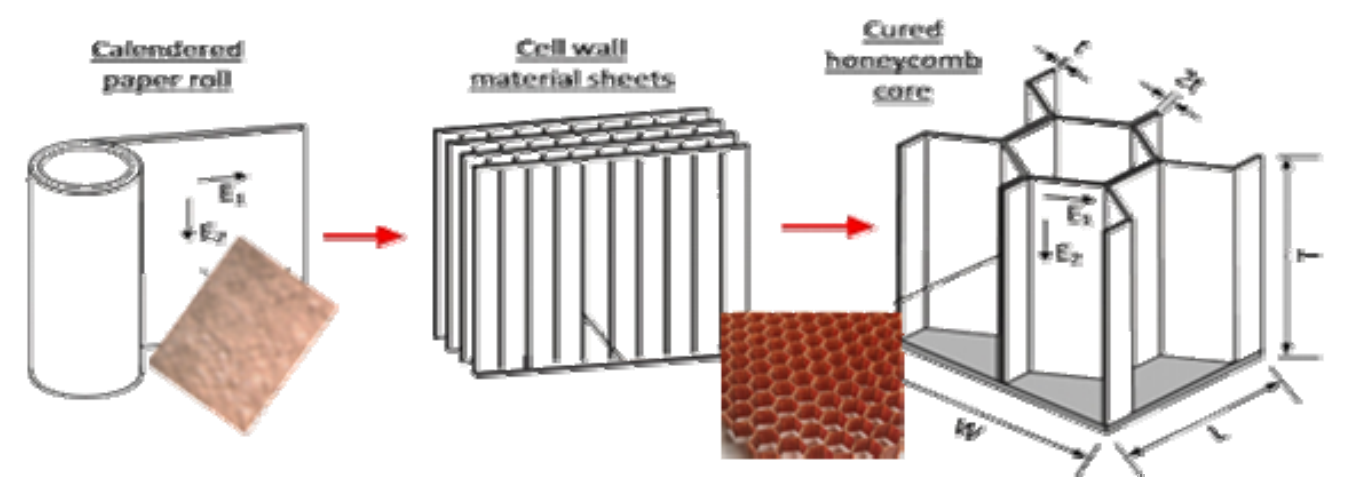

Figure 3. Honeycomb manufacturing process

In previous relation $\mathrm{Q}_{i j}$ are reduced stiffness of the orthotropic thin plate, and $\mathrm{E}_{i}, \mathrm{G}_{i j}$ and $\gamma \mathrm{ij}$ are engineering elastic coefficients.

It is worth mentioning that stiffness matrix is always symmetric therefore the relation between major and minor Poisson ratio (based on stiffness matrix symmetry) is given as:

$$
\frac{v_{12}^{p} E_{90}^{p}}{1-v_{12}^{p} v_{21}^{p}}=\frac{v_{21}^{p} E_{0}^{p}}{1-v_{12}^{p} v_{21}^{p}} \Rightarrow v_{21}^{p}=\frac{v_{12}^{p} E_{90}^{p}}{E_{0}^{p}}
$$

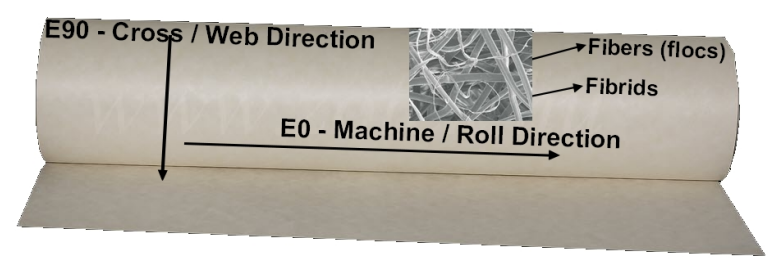

Figure 4. Nomex paper orthotropic Structure

The values of Young's moduli of Nomex paper, of various paper thicknesses, are experimentally obtained and can be found in [10] and [12][5]. The summary is given in Table 2.

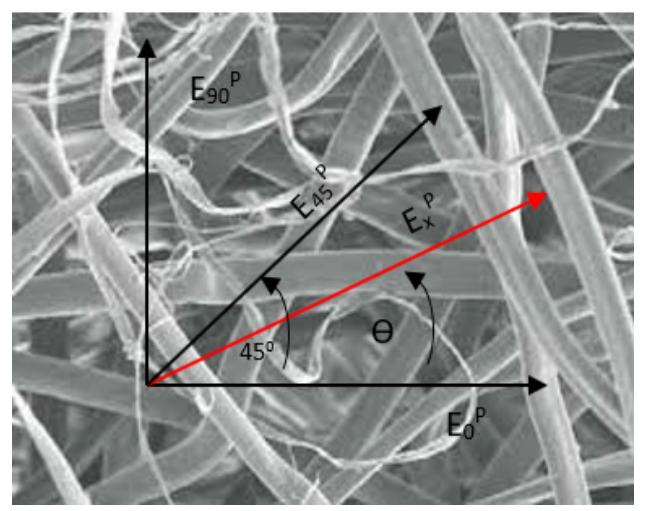

Figure 5. Nomex Paper reference Microstructure and analysis reference coordinate system

For an axis, at an arbitrary angle in paper plane, measured from machine direction, the Young's modulus of elasticity for that direction can be expressed as [13]:

$$
\begin{aligned}
& \frac{1}{E_{x}^{p}}=\frac{m^{2}}{E_{0}^{p}}\left(m^{2}-n^{2} v_{12}^{p}\right)+ \\
& +\frac{n^{2}}{E_{90}^{p}}\left(n^{2}-m^{2} v_{21}^{p}\right)+\frac{m^{2} n^{2}}{G_{12}^{p}}
\end{aligned}
$$

The previous equation represents known transformation relation of in-plane Young's modulus for a desired direction, expressed as a function of Young's moduli in a machine and roll paper direction, major and minor Poisson's ratios and the in-plane shear modulus of the paper. The values of $m$ and $n$ are sine and cosine values of the transformation angle.

The similar approach can be used to obtain the value of transformed in-plane moduli of the paper. The equation for the transformation of the in-plane paper shear modulus can be written as:

$$
\begin{aligned}
& \frac{1}{G_{x y}^{p}}=\frac{4 m^{2} n^{2}}{E_{0}^{p}}\left(1+v_{12}^{p}\right)+ \\
& +\frac{4 m^{2} n^{2}}{E_{90}^{p}}\left(1+v_{21}^{p}\right)+\frac{\left(m^{2}-n^{2}\right)^{2}}{G_{12}^{p}}
\end{aligned}
$$

Based on experimentally obtained values for Nomex paper of thickness $0.05 \mathrm{~mm}$ for Young's moduli in machine direction, roll direction and in the direction $45^{\circ}$ by Roy et.al and reported in [10], the previous equations (equations 3 and 4), for transformation angle of $45^{\circ}$ and using stiffness matrix symmetry (equation 2) can be written in the following form:

$$
\begin{aligned}
& \frac{1}{E_{45}^{p}}=\frac{1}{4}\left(\frac{1-v_{12}^{p}}{E_{0}^{p}}+\frac{1-\frac{v_{12}^{p} E_{90}^{p}}{E_{0}^{p}}}{E_{90}^{p}}+\frac{1}{G_{12}^{p}}\right) \\
& \frac{1}{G_{12}^{p}}=\frac{1}{E_{45}^{p}}\left(1+v_{12}^{p}\right)+\frac{1}{E_{90}^{p}}\left(1+\frac{v_{12}^{p} E_{90}^{p}}{E_{0}^{p}}\right) .
\end{aligned}
$$

Simultaneously solving equations 4 and 5 , the unknown in-plane shear modulus and major Poisson ratio of the Nomex paper of thickness $0.005 \mathrm{~mm}$ can be obtained.

Using this approach, all elastic coefficients for Nomex paper $(0.05 \mathrm{~mm}$ thick) are calculated and summarized in table 1 .

To determine all required elastic coefficients of Nomex paper of thickness $0.13 \mathrm{~mm}$ experimental results reported by Foo et al. are used. For low to moderate orthotropic materials Tsui equation can be used, as 
additional equation to the elastic coefficients system of equations (equations 4 and 5).

For the Nomex paper Tsui Equation [14]is expressed as:

$$
G_{12}^{p}=\frac{0.7}{1.3\left(0.4 / E_{90}^{p}+1 / E_{0}^{p}\right)} .
$$

The results obtained for the Nomex paper, $013 \mathrm{~mm}$ thick, are calculated and summarized in the Table 1.

\subsection{Phenolic resin elastic coefficients}

Phenol formaldehyde or phenolic resins are synthetic polymers obtained by the reaction of phenol with formaldehyde.

In general, phenolic resins have been used for the production of different types of moulded products. Phenolic resins can be produced using one of two main production methods.

One is based on the reaction of phenol and formaldehyde directly to produce a thermosetting network polymer, while the other restricts the formaldehyde to produce a prepolymer known as novolac. Hardened phenolic plate is shown in the following picture (Figure $6)$.

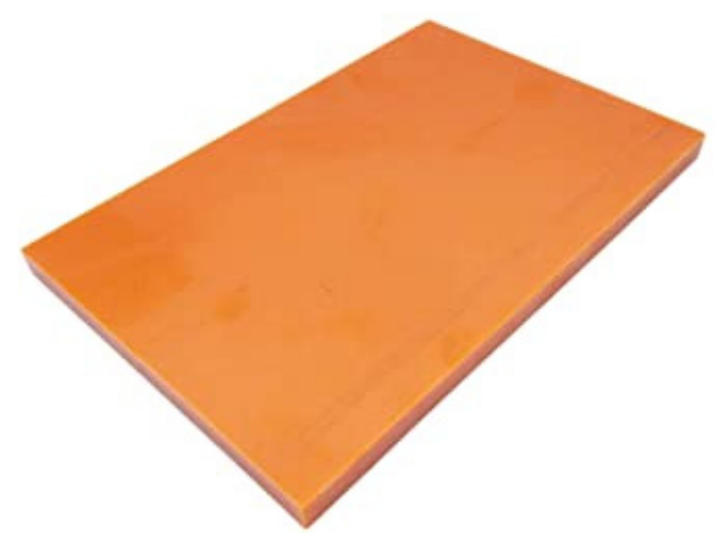

Figure 6. Phenolic resin plate

Unlike Nomex paper, phenolic resin coating, in which the paper is dipped and cured during Nomex core production process, the phenolic coating itself, exhibits pure isotropic behaviour. Equation 1 is valid for isotropic materials as well and can be obtained by equivalation of all Young modulii and Poisson's ratios (major and minor).

$$
\left[\begin{array}{c}
\sigma_{0} \\
\sigma_{90} \\
\tau_{12}
\end{array}\right]=\left[\begin{array}{ccc}
\frac{E_{1}}{1-v_{12}^{2}} & \frac{v_{12} E_{1}}{1-v_{12}^{2}} & 0 \\
\frac{v_{12} E_{1}}{1-v_{12}^{2}} & \frac{E_{1}}{1-v_{12}^{2}} & 0 \\
0 & 0 & G_{12}^{\text {phen }}
\end{array}\right]\left[\begin{array}{c}
\varepsilon_{0} \\
\varepsilon_{90} \\
\gamma_{12}
\end{array}\right]
$$

Furthermore, for all isotropic materials the relation between Young's modulus, shear modulus and Poisson's ratio is known and can be expressed in the following form:

$$
G_{12}^{\text {phen }}=\frac{E_{1}}{2\left(1+v_{12}\right)} .
$$

Therefore, to fully describe stress-strain behaviour of the phenolic coating two independent elastic coefficients are needed and are usually obtained by the material manufacturer for the prescribed curing process.

At present, the literature provides only a few experimental references for phenolic resin mechanical properties. Phenolic resin experimentally obtained mechanical values, found in literature are summarized in Table 2.

Table 1: Phenolic resin mechanical data

\begin{tabular}{|l|c|c|c|c|}
\hline \multirow{2}{*}{$\begin{array}{l}\text { Phenolic } \\
\text { Resin }\end{array}$} & $\mathrm{E}$ & $v$ & $\mathrm{G}^{1}$ & $\rho$ \\
\cline { 2 - 5 } & {$[\mathrm{MPa}]$} & {$[-]$} & {$[\mathrm{MPa}]$} & {$\left[\mathrm{g} / \mathrm{cm}^{3}\right]$} \\
\hline Redjel [15] & 5160 & 0.36 & & 1.25 \\
\hline Roy [10] & 4940 & 0.389 & & 1.342 \\
\hline Liu [[16]] & 5800 & 0.389 & & 1.38 \\
\hline
\end{tabular}

Calculated value

\subsection{Nomex paper / Phenolic coating material}

As it was mentioned earlier, during Nomex core production process, the calendared Nomex paper is dipped into the phenolic resin and cured to obtain very stiff and strong structure. To analyse the stress-strain behaviour of composite plates with Nomex core numerical model was created. The RVE element as a main building block for the core is presented in the following picture (Figure 7).

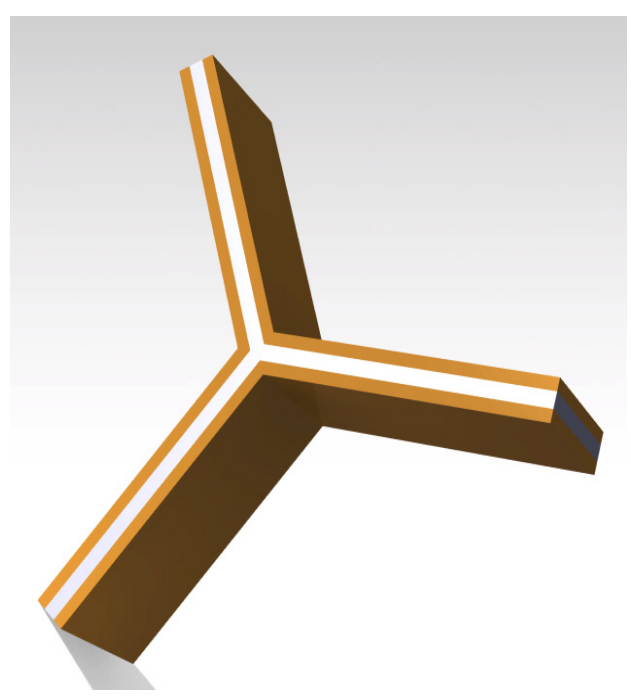

Figure 7. Nomex paper with phenolic coating RVE element.

As depicted in previous picture, the nomex paper of selected thickness is located in the central zone of the RVE, whereas the phenolic coating is located on the sides. The thickness of the phenolic coating is usually determined experimentally by measuring the total thickness of the Nomex core wall. Once the total thickness is known, the value of the paper thickness is subtracted from the measured value of the wall thickness and the result is divided by two assuming even distribution of the resin along the paper surfaces. 
Table 2: Nomex paper elastic coefficients (experimental and calculated) for various thicknesses

\begin{tabular}{|l|c|c|c|c|c|c|c|}
\hline \multicolumn{1}{|c|}{$\begin{array}{c}\text { Nomex Paper } \\
\text { T410 }\end{array}$} & $\mathrm{t}$ & $\mathrm{E}_{0}{ }^{\mathrm{p}}$ & $\mathrm{E}_{45}{ }^{\mathrm{p}}$ & $\mathrm{E}_{90}{ }^{\mathrm{p}}$ & $\mathrm{G}_{12}{ }^{\mathrm{p}}$ & $\gamma_{12}{ }^{\mathrm{p}}$ & $\gamma_{21}{ }^{\mathrm{p}}$ \\
\cline { 2 - 8 } & {$[\mathrm{mm}]$} & {$[\mathrm{GPa}]$} & {$[\mathrm{GPa}]$} & {$[\mathrm{GPa}]$} & {$[\mathrm{GPa}]$} & {$[-]$} & {$[-]$} \\
\hline R. Roy et al [10] & 0.05 & 3.18 & 2.36 & 1.96 & $1.038^{1}$ & $0.28^{1}$ & $0.02^{1}$ \\
\hline Foo et al. [12] & 0.13 & 3.40 & - & 2.46 & - & - & - \\
\hline
\end{tabular}

${ }^{1}$ Calculated value

This approach would give reasonably correct result for the thickness of the phenolic coating provided that the measurement is taken on a single thickness wall of the Nomex core cell (Figure 8.).

The thickness of the phenolic coating is expressed as follows (equation 9):

$$
t_{\text {phen }}=\frac{\left(t_{s w}-t_{p}\right)}{2}
$$

In previous equation $t_{\text {phen }}$ is the thickness of the phenolic coating, $t_{\mathrm{sw}}$ is the total thickness of the single wall of the cured Nomex core and $t_{p}$ is the thickness of the Nomex paper used to manufacture the complete core.

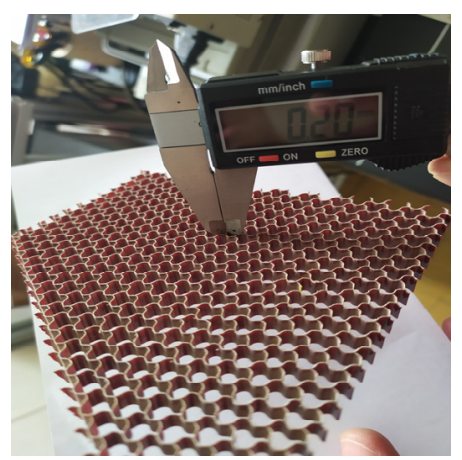

Figure 8. Nomex core wall thickness measurement

Previous method requires that the values $t_{s w}$ and $t_{p}$ are known. Manufacturer data usually provides the data of the density of the components. Thickness of the phenolic coating can be calculated provided that the densities of the components are known (paper and phenolic resin). For certain types of phenolic resins, that can be used for core production densities are given in Table 1. Densities of the Nomex paper, type 410, based on manufacturer data are given on the following graph (Figure 9).

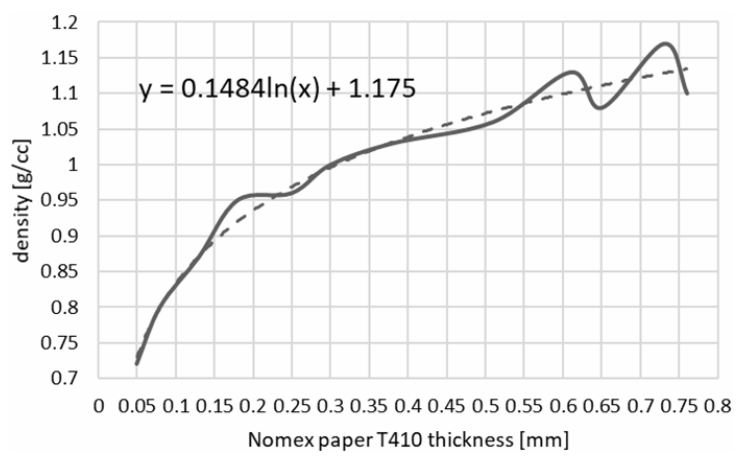

Figure 9. Nomex paper T410 density vs thickness

Once all elastic coefficients for all the phases of the core are calculated (for Nomex paper and phenolic resin coating), numerical model of the core was created.
The core was modeled using laminate finite elements consisting of three layers of different material properties and different thicknesses. Middle layer corresponds to pure Nomex paper of selected thickness (Table 2), whereas outer layers are phenolic resin coatings with properties listed in Table 2 and thickness calculated as previously explained (Equation 9). In certain zones, as a result of manufacturing process, core wall has a double thickness (Figure 10). These zones are modeled with the laminate finite elements similar to single walls, however double walls consist of four layers with same material properties and thicknesses as in single wall. Furthermore, the machine direction of the pure nomex paper, after calendaring process is coincident with the out of plane axis of the manufactured core. The laminate finite elements, both, used to model single and double walls, with machine direction indicated are presented in the following picture:

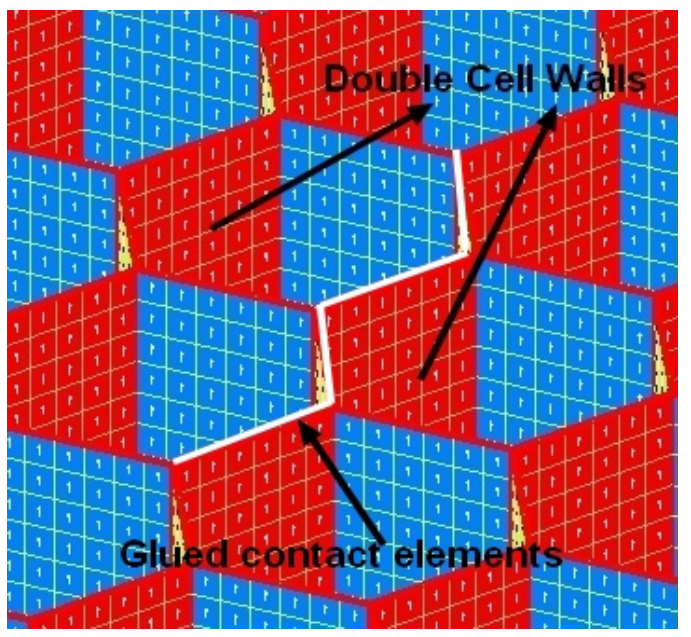

Figure 10.Nomex core FEA model.

\section{NUMERICAL MODEL}

To verify the correctness and validity of material model analysed in this paper, numerical model was created. Using finite element approach, Nomex core with top and bottom composite plate beam model was discretized with 46519 Laminate plate elements based on Classical lamination theory (CLT) [17]. The three point bending test as per ASTM C393/C393M - 11 [18] was numerically simulated. Contact between top and bottom beam plate with honeycomb core is simulated by adding contact elements in the area of contact zone (edge to surface glued contact). Contact elements enable load transfer between structure components with dissimilar finite element meshes (in this case between core and plates) with minimal processing time increase. The position of glued contact elements (only three shown for 
clarity) are shown in Figure 10. Using Nastran explicit solver (SOL 700) solution for displacement, strain and stress fields is obtained for all the components and component layers of the structure. The boundary conditions are modeled as follows: rigid body elements are used to model contact areas between the structure and supports. All DOF's were restrained in this area. The zone where the loading force is applied is also modeled using same type of elements, and the force evenly distributed along the width of the specimen. All dimensions, distances between supports and location of the load application is taken in respect to ASTM C393/C393M - 11.

Complete finite element model with pertinent boundary conditions is presented in the following picture (Figure 11).

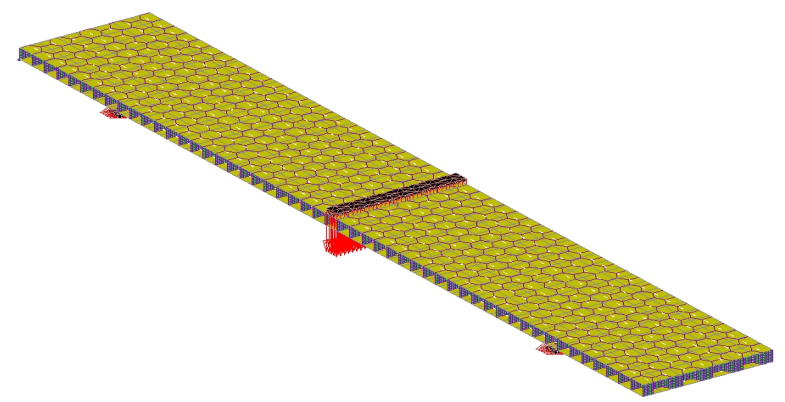

Figure 11. Finite element model

Material characteristics for the honeycomb core are calculated based on the material model proposed and presented in paragraph 2. Plates (top and bottom) are modeled as thin composite plates of thickness $t=1 \mathrm{~mm}$, where fibers are E-glass embedded in epoxy matrix. For this type of composite (M10E / 3783), manufacturer data for all relevant elastic coefficients (Young's modulii, shear modulus and Poisson's ratio) are given: $\mathrm{E}_{1}=24.5 \mathrm{GPa}, \mathrm{E}_{2}=23.8 \mathrm{GPa}, \mathrm{G}_{12}=4.7 \mathrm{GPa}$ and $v_{12}=0.28$. For the thin composite plate these four elastic coefficients are required to relate stresses and strains based on generalized Hooke's law [13]. These data corresponds to fiber volume fraction of $\mathrm{Vf}=0.50$ where fibers are in the form of plain weave.

The displacement field for the applied load of $\mathrm{F}=1500 \mathrm{~N}$ is presented in the following picture:

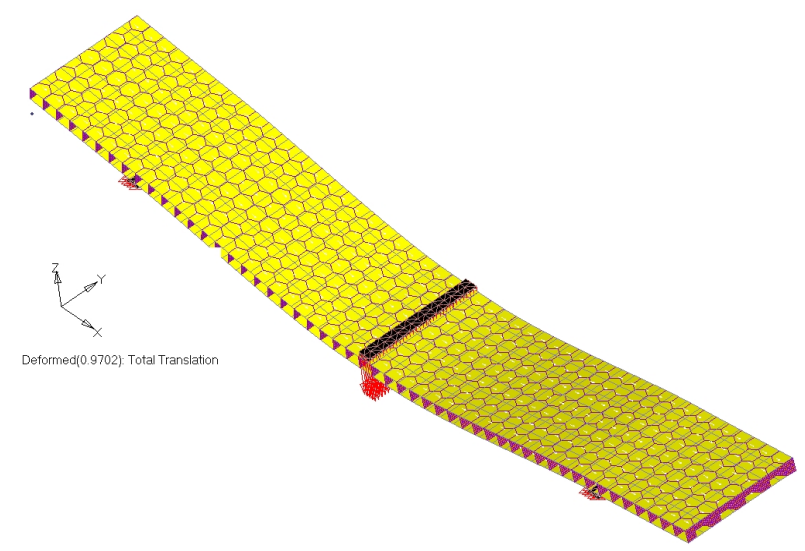

Figure 12. Beam displacement field (3 point bend test)

For the topmost plate layer (the most stressed layer in the structure) the stress field (Normal stresses in $\mathrm{X}$ direction) is presented in the Figure 13.

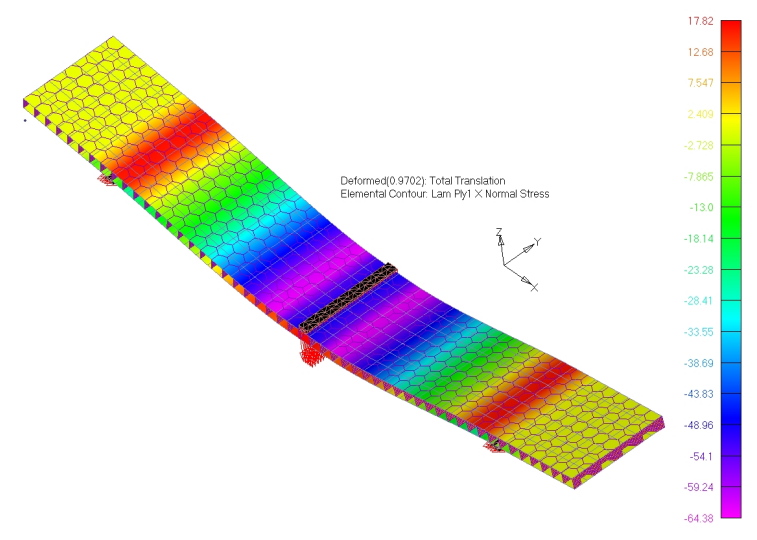

Figure 13. Normal stress in top plate, Layer 1.

The honeycomb core primarily carries shear stresses. The shear stress field, for the central core zone is presented in the following picture:

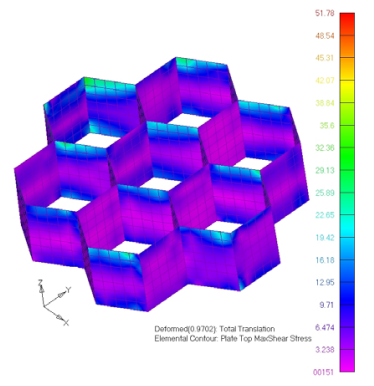

Figure 14. Shear stress distribution in the honeycomb core ( at beam midspan)

\section{EXPERIMENTAL VERIFICATION}

The proposed honeycomb material model was verified experimentally by manufacturing composite plates with Nomex honeycomb core. To ensure repeatability total of five plates of same dimensions and material characteristics were manufactured. Dimensions were in accordance with ASTM C393/C393M - 11 [18]. The length of specimens were $\mathrm{L}=400 \mathrm{~mm}$ and $10 \mathrm{~mm}$ core height with $1 \mathrm{~mm}$ thick top and bottom quasi-isotropic plates (plain weave). Manufactured specimens were subjected to three point bend testing, using $100 \mathrm{kN}$ Shimadzu servo-hydraulic test system ( model EHF EV101K3).

A complete test three point bend test setup is shown in the following picture (Figure 15).

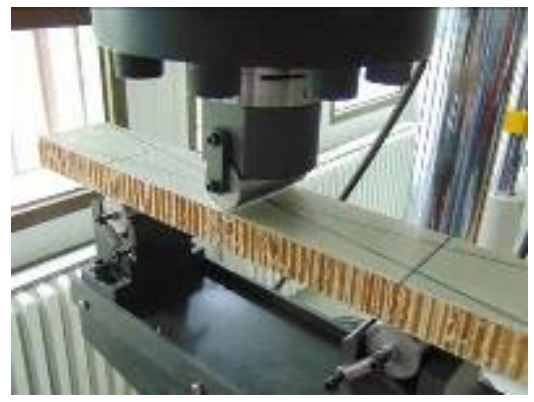

Figure 15. Three point bend test setup

After load application (quasi-steady) the load displacement curve shows a linear ramp, followed by the failure of the outermost layer of the top plate. As the load increases the sharp drop of stresses is observed and the load-displacement curve becomes highly non-linear. 
With the further load increase the core of the beam starts to yield and cracks in all the layers of the outer plate are evident. The load-displacement graph is presented in Figure 16.

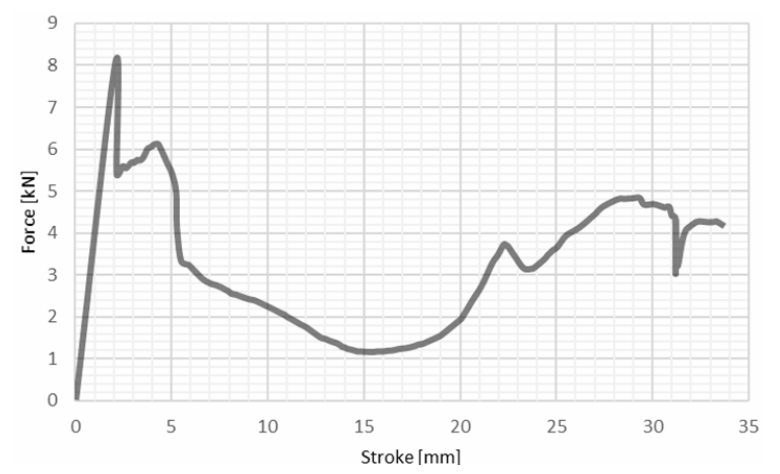

Figure 16. Load vs displacement graph

The loaded composite beam under three point bend test is presented in Figure 17.

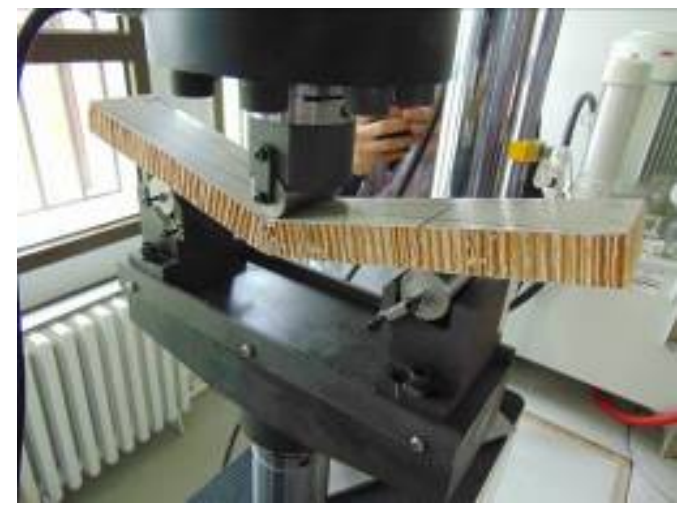

Figure 17. Loaded beam before top plate failure

The top plate failure is presented in the following figure (Figure 18):

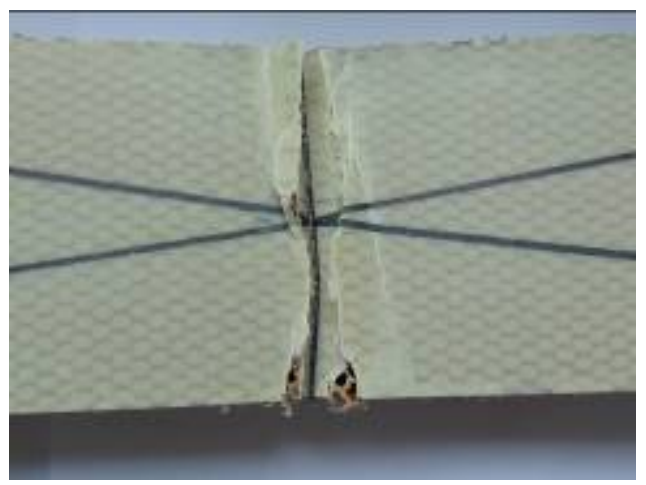

Figure 18. Top plate failure

\section{CONCLUSION}

In the present work material model for Nomex core (Nomex paper T410 coated with phenolic resin), based on experimental data is presented. It was concluded that in order to correctly predict stresses and displacements in the honeycomb core effective material models are not sufficient and material models at meso and micro level have to be deployed. This type of modeling can be done using present finite element algorithms. During experimental phase of this research it was observed that analyzed structure exhibits linear behaviour up to top plate failure followed by the highly non-linear behviour when the core starts to yield. To predict linear behaviour of this type of structures linear finite element solvers may suffice, where as for the non-linear behaviour explicit solvers are required.

\section{REFERENCES}

[1] Kassapoglou C.: Design and analysis of composite structures (with applications to aerospace structures). Wiley; 2010.

[2] Garinis, D., Dinulović, M. and Rašuo, B. : Dynamic Analysis of Modified Composite Helicopter Blade, FME Transactions (2012) 40, 63-68

[3] Rašuo, B.: Aircraft Production Technology, Faculty of mechanical engineering, Belgrade, 1995, (in Serbian).

[4] Imran, A. and Jun., Y. J.:, Mathematical Models for in-Plane Moduli of Honeycomb Structures-A Review, Research Journal of Applied Sciences, Engineering and Technology vol. 7(3): pp. 581592, 2014.

[5] Albracht, F., Altenbach, H. and Nast, E.: On The Prediction Of Effective Elastic Moduli Of Honeycomb-type Sandwich Plates, Transactions on Engineering Sciences vol 10, 1996.

[6] Seemann R, Krause D. Numerical Modeling of Nomex Honeycomb Sandwich Cores at Meso-Scale Level. Compos Struct 2017; 159:702-18.

[7] A. Needleman: Computational Mechanics At The Mesoscale, Acta Materialia 48(1):105-124, 2000.

[8] V.,Panin: Physical Mesomechanics of Heterogeneous Media and Computer-Aided Design of Materials, Cambrige International Science Publishing, Cambridge, 1988.

[9] L. Mishnaevsky Jr, and S. Schmauder: Continuum mesomechanical finite element modeling in materials development: a state-of-the-art review, Applied Mechanics Reviews, 54 (1), 49-69 (2001).

[10]R., Roy, S.J. Park, J.H. Kweon and J.H Choi: Characterization of Nomex honeycomb core constituent material mechanical properties, Composite Structures 117 (2014) 255-266.

[11]Design of Materials, Cambrige International Science Publishing, Cambridge.

[12] C.C. Foo., G., B., Chai and L. Seah: Mechanical properties of Nomex material and Nomex honeycomb structure, Composite Structures 80 (2007) 588-594.

[13] I.M. Daniel and O., Ishai: Engineering mechanics of composite materials (2nd Edition), Oxford University Press, 2006.

[14] Y. Tsujii, K. Tanaka and Y.Nishida: Analysis of Mechanical Properties of Aramid Honeycomb Core : Investigation on the Compression Strength and the Shear Modulus, Transactions of the Japan Society of Mechanical Engineers Series A, Volume 61 Issue 587, 1995.

[15]B. Redjel.: Mechanical properties abd fracture toughness of phenolic resin. Plastics, Rubber and 
Composites Processing And Applications; 24:2218, 1995.

[16] L. Liu, H, Wang and Z. Guan: Experimental and numerical study on the mechanical response of Nomex honeycomb core under transverse loading. Composite Structures, Volume 121, pp. 304-314, 2015.

[17] E. J. Barbero: Finite Element Analysis f Composite Materials, Taylor \& Francis Group, 2008.

[18] Standard Test Method for Core Shear Properties of Sandwich Constructions by Beam Flexure, ASTM C393/C393M - 11

\section{НУМЕРИЧКО МОДЕЛИРАҢЕ КОМПОЗИТНИХ ПЛОЧА СА НОМЕХ САЋАСТОМ ИСПУНОМ НА МЕЗО НИВОУ}

\author{
М. Динуловић, Б. Рашуо, М.Р. Трнинић, \\ B.M. Аџић
}

Композитне плоче са саћастом испуном се све више користе при изради примарних ваздухопловних структура. Ови материјали користе се при конструкцији оплата трупова летелица, централних и спољних торзионих кутија крила, оплата погонских група, врата стајних трапова, командних површина као што су спојлери и елерони. Да би се одредила поља напона и деформација оптерећене структуре неопходно је познавање свих еластичних коефицијената. У овом раду, метод за одређивање свих потребних еластичних коефицијената испуне и плоча је представљен. Користећи се експериментално добијеним резултатима за папир НOMEX (тип 410 ) као и фенолну матрицу материјални модел је представљен, израђен је модел коначних елемената композитне плоче са саћастом испуном и нумерички је симулиран тест савијања у три тачке. Добијени резултати упоређени су са резултатима добијеним експериментом. Примећено је добро слагање између предложеног модела материјала и експериментално добијених вредности 